Marquette University

e-Publications@Marquette

Theology Faculty Research and Publications

Theology, Department of

$10-1-2014$

\title{
Toward a Catholic Malcolm X?
}

Bryan N. Massingale

Marquette University, bryan.massingale@marquette.edu

Published version. American Catholic Studies, Vol. 125, No. 3 (Fall 2014): 8-11. DOI. (C 2014 Villanova University. Used with permission. 


\title{
Toward a Catholic Malcolm X?
}

\author{
Bryan N. Massingale ${ }^{5}$
}

I confess to being a bit surprised when I was invited to participate in a discussion concerning the state of "critical Catholic Studies." I often experience that my interests and concerns - especially regarding racial justice and the intersections of race and sexuality - are not at the core of what might be commonly construed as "Catholic." At best, these matters are peripheral or marginal to what many consider to be a genuinely Catholic intellectual enterprise.

So, to honor the request that we be direct, pointed, provocative, and brief in our contributions, I will focus mine upon the following questions: Is there room in the discipline of Catholic Studies for a Catholic Malcolm X? Or better stated (presuming a too facile affirmative reply), what kind of space would be allowed or allotted for his/her voice? Is a "Catholic Malcolm X" an oxymoron or impossibility in Catholic Studies? To broaden my questions beyond a specific figure, I ask: Is there space for black religious radicalism in Catholic Studies? ${ }^{6}$ Should there be? Let me explain the questions.

I titled my 2010 CTSA Presidential Address, "Vox Victimarum, Vox Dei: Malcolm X as Neglected 'Classic' in Catholic Theological Reflection."7 I wanted to signal to the Catholic guild of scholars not only the necessity of engaging the Black experience, but also the need to engage the entirety of that cultural experience - including currents of Black Nationalist or radical race thought - instead of only those aspects of the Black experience considered safe or unthreatening. ${ }^{8}$ I was later

5. Bryan N. Massingale is professor of theological ethics at Marquette University. His research and publications focus on Catholic social thought, racial justice, and the intersections of race and sexuality in Catholicism. He is a former president of the Catholic Theological Society of America and a past convener of the Black Catholic Theological Symposium. Contact: bryan.massingale@marquette.edu.

6. Gayraud S. Wilmore identifies three characteristics of what he calls the "radical tradition in black religion," namely: "(1) the quest for independence from white control; (2) the revalorization of the image of Africa; and (3) the acceptance of protest and agitation as theological prerequisites for black liberation and the liberation of all oppressed peoples" (Black Religion and Black Radicalism: An Interpretation of the Religious History of African Americans, 3rd ed. [Maryknoll, NY: Orbis Books, 1998], ix). I am not saying that this is the only possible definition of black religious radicalism, but it hints at what I am trying to suggest is problematic and lacking in the discipline of Catholic Studies up to now.

7. CTSA Proceedings 65 (2010): 63-88.

8. For example, Martin Luther King, Jr., seems the apparent dialogue partner of choice for the majority of white Catholic scholars who avert to black contributions in theology or religion. Yet even with this iconic figure, Catholic intellectuals tend to 
told that some of those in attendance, upon discovering the title in the convention program, remarked, "Has Bryan lost his mind?" After the address, a colleague admitted in an email that while grateful that I had addressed this topic, s/he would never have done so, given what my colleague called "the bourgeois nature of the CTSA and Catholic theology." These reactions are telling and indicative of the problem with not only Catholic theology, but also with the way "Catholic Studies" as the field is usually and commonly construed. For in the U.S. context, Catholic intellectual engagement is marked by a dearth of serious engagement with black radical thought and critique.

To further explain: By a space for a "Catholic Malcolm X," I mean the reconstitution of Catholic Studies through its encounter with subversive voices which, like Malcolm's, would boldly declare, "Catholicism has failed us." And by "us," these voices would intend not only African Americans but all racial identities. Because all are harmed by the reason for Catholicism's failure - and by extension, Catholic Studies' failure, insofar as Catholic Studies engages and reflects upon Catholic life and practice: "It's failure to address racism."9 By calling for a reconstitution of Catholic Studies, I contend that its marginal considerations of race or episodic forays with either critical race studies or radical black thought are not simply sins of omission that can be rectified through an expanded reading list or the addition of authors of color to an accepted canon. Rather, this limited engagement with the reality of racialization and its injustices stems from a fundamentally idolatrous symbol system of a white God. ${ }^{10}$ The consequence of this idolatrous symbol system is that for Catholic Studies, "Catholic" = "white." Thus what makes Catholic Studies "white" is not the racial identity of the majority of its participants, but the pervasive, albeit

consider only the addresses and writings of the early part of his public ministry and neglect the more radical ideas and provocative positions he espoused in the last years of his life. On this point, see Kenneth L. Smith, "The Radicalization of Martin Luther King, Jr.: The Last Years," Journal of Ecumenical Studies 26 (1989): 270-288.

9. Malcolm X, The Autobiography of Malcolm X (New York: Ballantine Books, 1965), 425. Note that Malcolm's original indictment was of the entirety of Christianity. The specification of Catholicism is my own, though entirely consistent with Malcolm's worldview.

10. Attributing Catholicism's complicity in racial omission, silence, and injustice to a form of idolatry is an emerging feature of recent Catholic reflection on race. See the following: M. Shawn Copeland, Enfleshing Freedom: Body, Race, and Being (Minneapolis: Fortress Press, 2010); Bryan N. Massingale, "Response: The Challenge of Idolatry and Ecclesial Identity," in Ecclesiology and Exclusion: Boundaries of Being and Belonging in Postmodern Times, ed. Dennis M. Doyle, et al., (Maryknoll, NY: Orbis Books, 2012), 130-135; Jon Nilson, "Towards the 'Beloved Community': The Church's Role in the Struggle against Racism," U.S. Catholic Historian 28 (Winter 2010): 83-91; and Bryan N. Massingale, "Has the Silence Been Broken? Catholic Theological Ethics and Racial Justice," Theological Studies 75 (March 2014): 133-155. 
tacit, conviction that "Western European aesthetics, music, theology, and persons - and only these - are standard, normative, universal, and truly "Catholic."11 A discipline constituted by a normative whiteness will have very limited space for a Catholic Malcolm X, to say the least. To create such a space would entail a thorough-going revision, not a modest retooling.

This is the essence of Black Radicalism: it is nothing less than a passionate commitment to the subversive conviction that black people indeed all persons of color - are fully human. Regardless of disagreements over tactics and rhetorical expression, what unites black radicals is an unwavering commitment to the full humanity of black people. What makes this a radical undertaking is the forthright and candid recognition that asserting the full humanity of black people remains still a subversive enterprise, for it challenges the foundations of Western identity and culture. Black radicalism, because of its conviction that white supremacy lies at the core of Western culture, unabashedly posits that the full humanity of black people cannot be completely realized without deep and fundamental - i.e., radical transformations in social, economic, and political institutions.

By a space for a Catholic Malcolm X in Catholic Studies, then, I mean a discipline that is wedded to a radical or deep analysis that understands "race" as central to the construction of Western (and global) social and religious life and as fundamental to personal and cultural identities. Such an analysis is, in all likelihood, not to be found outside of an encounter with radical voices in the black tradition. As the acclaimed essayist, Ta-Nehisi Coates, observes: "Black nationalists have always perceived something unmentionable about America that integrationists dare not acknowledge - that white supremacy is not merely the work of hotheaded demagogues, or a matter of false consciousness, but a force so fundamental to America that it is difficult to imagine the country without it."12 The inclusion of such voices within Catholic Studies would mean a discipline that would not only celebrate the contributions of a Catholic faith sensibility, but also humbly acknowledge its constraints, omissions, and blindspots - inadequacies that stem not only from collusions with social injustices but also a particularly Catholic commitment to the force of precedent which hinders the creative exploration of or engagement with new insights, much less those that come from the margins. ${ }^{13}$

11. Bryan N. Massingale, Racial Justice and the Catholic Church (Maryknoll, NY: Orbis Books, 2010), 80.

12. Ta-Nehisi Coates, "The Case for Reparations," The Atlantic (June 2014).

13. The eminent legal historian, John T. Noonan, Jr., observes: "Benefitted by precedent because precedent provided framework, direction, continuity, but 
Thus by a Catholic Malcolm X within Catholic Studies, I mean a discipline not only open to insights from the underside of U.S. life, but also one with the courage and humility to admit its errors, oversights, and cultural captivity, much as Malcolm admitted his errors and rearranged his thought patterns when confronted with the evidence that the "blond haired, pale skinned, blue eyed devil white man" could indeed relate to him as an equal. Is Catholic Studies, as currently and commonly understood, possessive of such courage and humility?

The noted Canadian philosopher and theologian, Bernard Lonergan, observed that we become conscious of our biases only by means of encounter, since "encounter is the one way in which selfunderstanding and horizon are put to the test." Encounter, he continues, means "meeting persons, appreciating the values they represent, criticizing their defects, and allowing one's living to be challenged at its roots by their words and deeds."14 Thus a Catholic Malcolm X would not be possible in Catholic Studies without that discipline risking such a genuine encounter with radical, even "strident and uncivil" voices, ${ }^{15}$ that is to say, not without a willingness on the part of the discipline to embrace a chastened humility. Such humility would also paradoxically signal a deep confidence that out of the difficulties of encountering such voices something new and more authentic might be born in the discipline.

Can Catholic Studies be so reconstituted as to embrace a Catholic Malcolm X? Or is the self-understanding of the discipline so constituted and committed to a normative whiteness that the possibility of genuine encounter with radical voices - to use Gustavo Gutierrez's memorable phrase - "from the underside of history" an unrealistic possibility? And if that is the case, then can Catholic Studies profess to make an adequate and valued contribution to reflecting upon the human experience in any way other than shoring up unjust social structures of racial privilege? These are among the crucial questions that a critical evolution of Catholic Studies must address. A Catholic Malcolm X would also require us candidly to recognize that such an evolution will require serious and sustained struggle, a struggle not only intellectual but also existential, from those who would both advocate and resist such an evolution.

handicapped by precedent because it discouraged initiative and openness to experience, moral doctrine has developed." See A Church That Can and Cannot Change (Notre Dame, IN: University of Notre Dame Press, 2005), 209, emphasis added.

14. Bernard Lonergan, Method in Theology (New York: Herder and Herder, 1972), 247, emphases added.

15. David Tracy, Plurality and Ambiguity: Hermeneutics, Religion, Hope (Chicago: University of Chicago Press, 1987), 79. 